MANNHEIM RESEARCH INSTITUTE FOR THE ECONOMICS OF AGING

\title{
WORK DISABILITY, HEALTH, AND INCENTIVE EFFECTS
}

Axel Börsch-Supan

( ) Mea-Mannheim Research Institute for the Economics of Aging

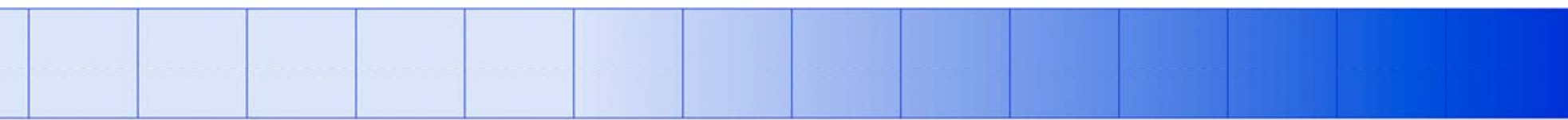

L13, 17_D-68131 Mannheim_Phone +49 621 181-2773/1862_Fax +49 621 181-1863_www.mea.uni-mannheim.de 


\title{
Work Disability, Health, and Incentive Effects
}

\author{
Axel Börsch-Supan \\ Mannheim Research Institute for the Economics of Aging (MEA), \\ Mannheim University, Germany \\ National Bureau of Economic Research (NBER), Cambridge, Mass., USA
}

\begin{abstract}
Disability insurance - the insurance against the loss of the ability to work - is a substantial part of social security expenditures in many countries. The enrolment rates in disability insurance vary strikingly across European countries and the US. This paper investigates the extent of, and the causes for, this variation, using data from SHARE, ELSA and HRS.

We show that even after controlling for differences in the demographic structure and health status these differences remain. In turn, indicators of disability insurance generosity explain $75 \%$ of the cross-national variation. We conclude that country-specific disability insurance rules are a prime candidate to explain the observed cross-country variation in disability insurance enrolment.
\end{abstract}

\author{
Address: \\ Prof. Axel Börsch-Supan, Ph.D. \\ Mannheim Institute for the Economics of Aging (MEA), \\ L13, 17 \\ Universität Mannheim \\ D-68131 Mannheim \\ Tel.: +49-621-181-1862 \\ Email: axel@,boersch-supan.de
}

Acknowledgements: I am grateful to Stephanie Stuck for generating the SHARE data extract, to Fabian Terner for merging ELSA and HRS data to it, and to Martin Prince and Susann Rohwedder for helpful comments. 


\title{
Work Disability, Health, and Incentive Effects
}

\author{
by Axel Börsch-Supan
}

\section{Introduction}

Disability insurance - the insurance against the loss of the ability to work - is a substantial part of public social expenditures and an important part of the social safety net of all developed countries. Like almost all elements of modern social security systems, disability insurance faces a trade-off: One the one hand, disability insurance is a welcome and necessary part of the social safety net as it prevents income losses for those who loose their ability to work before the normal retirement age. One the other hand, disability insurance may be misused to serve as an early retirement route even if the normal ability to work is not affected at all.

Understanding the trade-off between social safety provision and its misuse is important for the design of a modern social security system which maximizes social safety provision under increasingly tight financial budget constraints (Aarts et al. 1996). The aim of this paper is to use the newly collected SHARE data (the Survey of Health, Ageing and Retirement in Europe) together with data from its sister surveys in England (the English Longitudinal Study on Ageing) and the US (the Health and Retirement Study) to shed light on this trade-off.

Starting point for this paper is the striking variation of the expenditures on disability insurance across European countries and the US, see Figure 1. This and the two following figures are based on the official figures provided by the European Union, collected as part of the European System of Integrated Social Protection Statistics, which employ a harmonized definition of disability insurance. The data for the United States in Figures 1 and 2 are taken from OECD (2003), which uses a comparable definition, but is, unfortunately, only available for 1999.

While the EU15 countries (i.e., the fifteen countries that formed the European Union before its enlargement in 2005) spend about 8 percent of their social expenditures on disability insurance, it is about 14 percent in the Scandinavian countries, and about 10 percent in the UK and the US. IN turn, some countries, such as France, Greece and Ireland, spend only about 5 percent. 
Figure 1: Share of disability insurance expenditures in total expenditures (percentages)

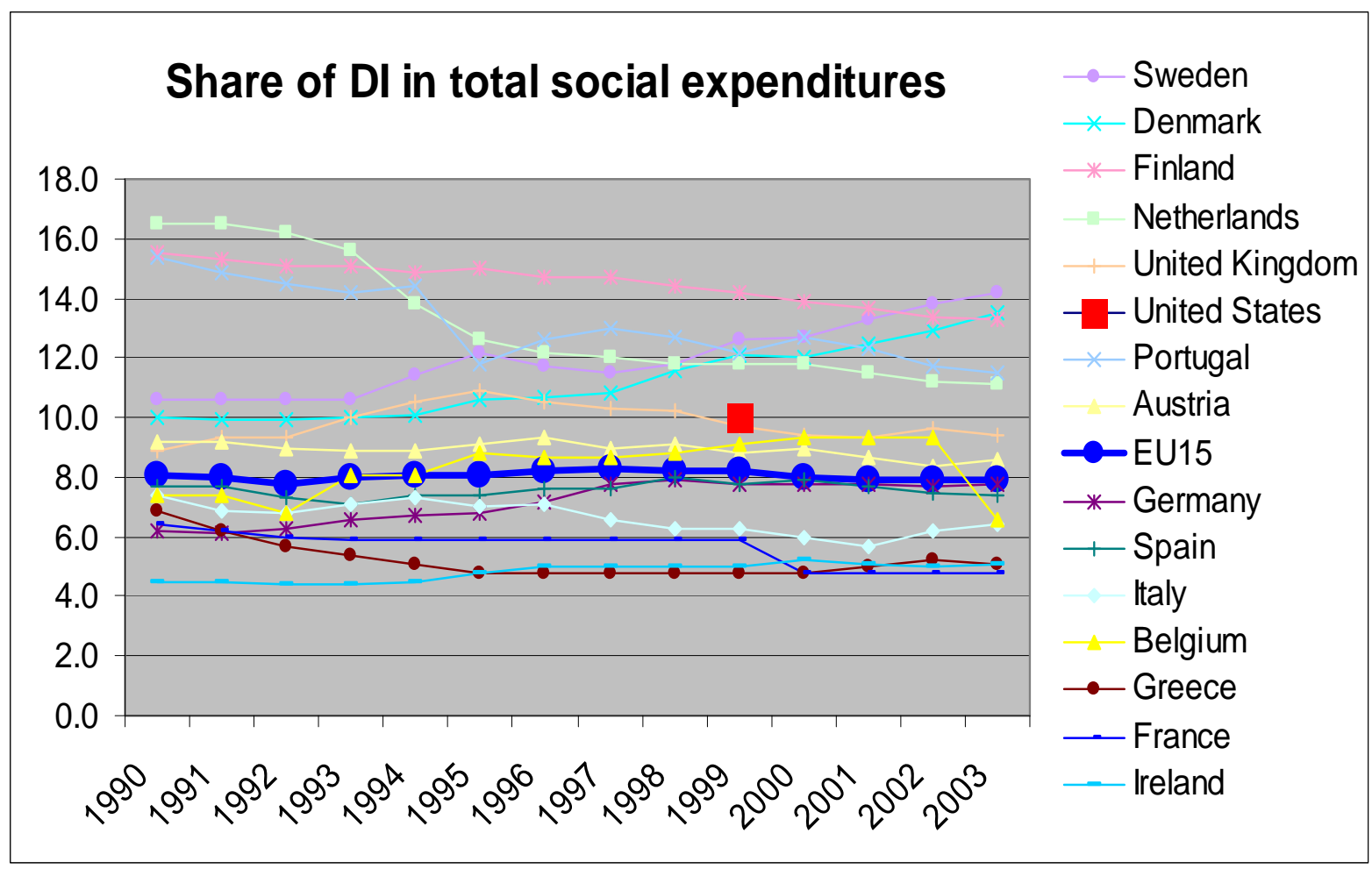

Source: Eurostat Data Archive 2005 and OECD 2003.

Figure 2: Disability insurance expenditures as percent of GDP (percentages)

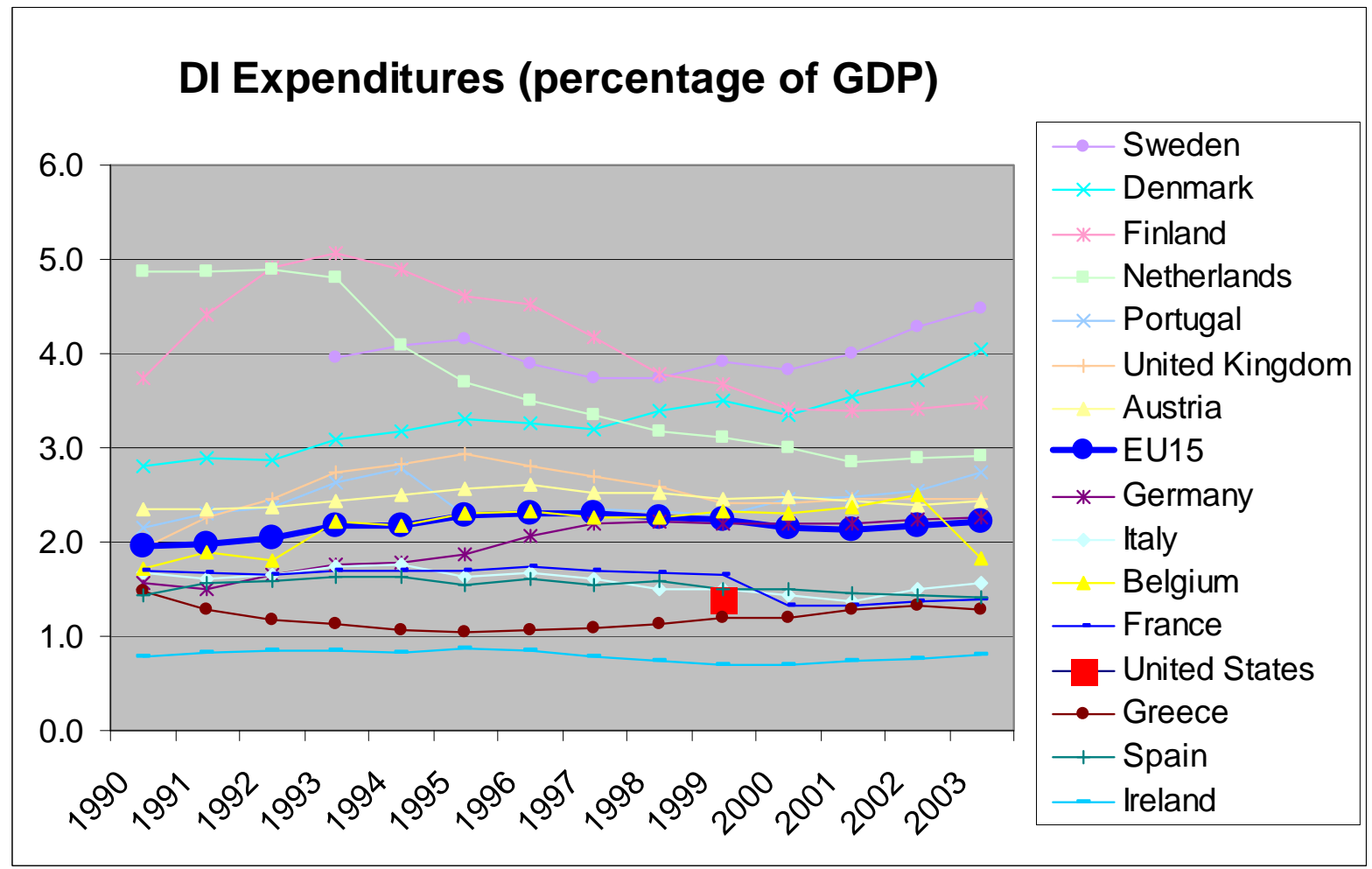

Source: Eurostat Data Archive 2005 and OECD 2003. 
As Figure 2 shows, this variation is not a matter of rich and poor countries: the order of countries and the range is about the same when correcting for GDP differences across countries. The only substantial change is the US: since their total social expenditures are about half of what they are in Europe, disability insurance expenditures as percentage of GDP are much smaller than the share of disability insurance in social expenditures.

While absolute expenditures have risen in all EU15 countries, see Figure 3, the pattern over time is also quite different across countries. Especially Sweden and Denmark exhibit a sharp increase since about the year 2000, while the Netherlands and Finland have somewhat stabilized their very large expenditures on disability insurance until the mid1990s.

The range of per capital expenditures is enormous, even after correcting for purchasing power differences within the European Union (including the countries in the Euro zone). Sweden and Denmark spend four to five times more on disability insurance than France and the Mediterranean countries. The US spending correspondents to $89 \%$ of the EU15 average.

\section{Figure 3: Disability insurance expenditures per capita (Euro, purchasing power parity)}

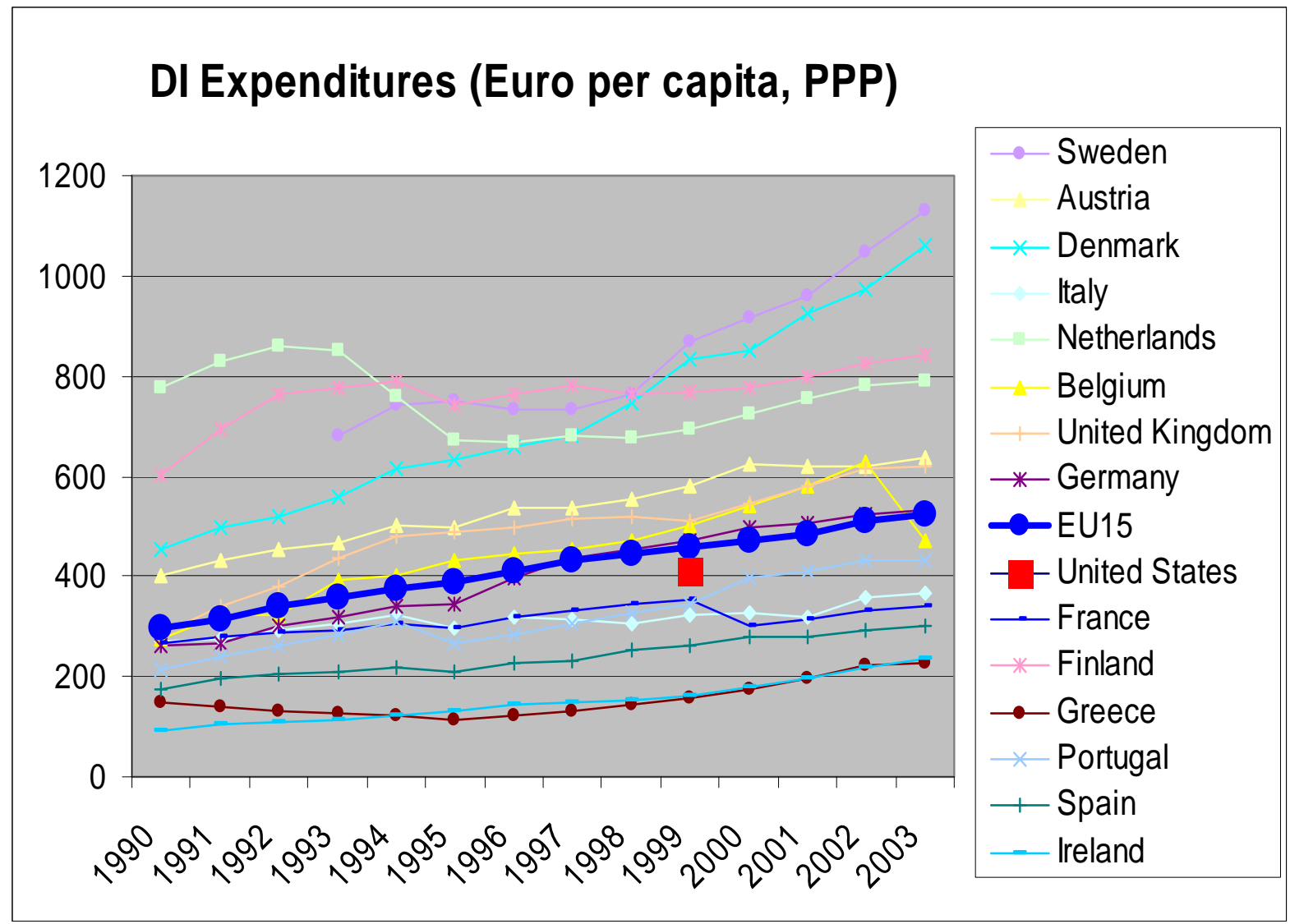

Source: Eurostat Data Archive 2005. 
The remainder of the paper is devoted to isolating the causes underlying the large crossnational variation of disability insurance expenditures and the different expenditure patterns over time visible in Figures 1 through 3.

Three causes are commonly mentioned to explain the large variation: demographics, health and institutions. First, while all European countries are aging, the extent of population varies considerably. Hence, the first explanation claims that a country with an older population also has a higher prevalence of disability insurance uptake. A second potential cause for the crossnational variation is differences in health status. Can differences in physical and mental health explain why disability insurance is taken up so much more frequently in some countries than in others? Third and finally, recent studies such as Blöndal and Scarpetta (1998) based on the Gruber and Wise (1999) methodology have shown that public old age pension systems exert large incentive effects which, according to each country's legislation, significantly increase the uptake of early retirement provisions. Do similar incentive effects arise also from disability insurance? Are differences in the European countries' legislations causing different disability insurance take-up rates?

Figure 4 may indicate that this is the case: some countries have an average age of withdrawal from the labor force which is considerably lower than the earliest eligibility age for old-age pensions.

\section{Figure 4: Retirement age in Europe}

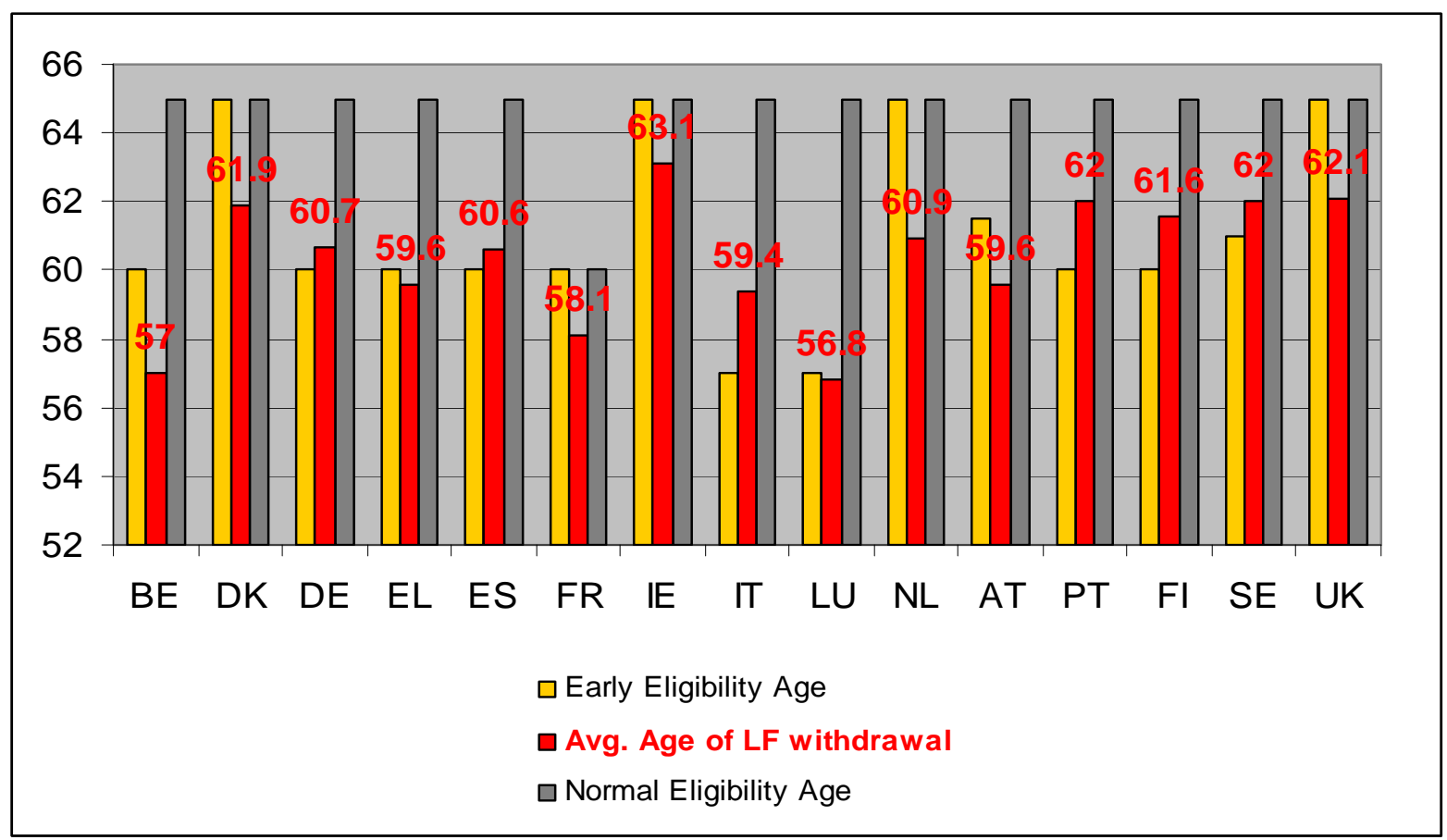

Source: European Commission (2003). 
Particular striking examples are Austria, Belgium, and France, where the average withdrawal age is younger than age 60. But also in Denmark and the United Kingdom, countries with a generally much higher retirement age, is the average withdrawal age below the earliest eligibility age for old-age pensions.

The paper proceeds as follows. Section 2 introduces the newly collected Survey of Health, Ageing and Retirement in Europe (SHARE) and describes how we merged comparable data from the English Longitudinal Study on Ageing (ELSA) and the US Health and Retirement Study (HRS). The section ends with a set of descriptive statistics characterizing our sample. The richness of these micro data permits us to estimate regressions which relate the uptake of disability insurance to demographic and health characteristics of the respondents in these surveys. Section 3 reports the result of these regressions, and Section ${ }^{\circ} 4$ applies them to a counterfactual exercise: how would disability uptake rates look like if there were no demographic and health-related differences among the 12 European countries and the US in our sample. As it turns out, demographic and health-related differences do not explain much of the crossnational variation. Section 5 therefore turns to incentive effects and regresses disability insurance on a set of incentive variables derived from recent OECD work. Our main result is that almost $75 \%$ percent of the cross-national variation can be explained by a parsimonious set of a few variables describing the generosity of, and the ease of access to, disability insurance. Section 6 concludes.

\section{SHARE, ELSA and HRS}

The Survey of Health, Ageing and Retirement in Europe is modeled closely after the U.S. Health and Retirement Study (see Juster \& Suzman 1995), the first survey of this kind, and the English Longitudinal Study of Ageing (see Marmot et al. 2003) which followed the lead by HRS. Researchers from HRS and ELSA have been participating in the design process of SHARE at all stages. About two-thirds of the variables in SHARE are identical to variables in ELSA and HRS, and most of the remainder is closely comparable. The longitudinal sequence of waves is synchronized among SHARE, ELSA and HRS. In 2006, HRS will collect its $6^{\text {th }}$ wave, ELSA the third, and SHARE the second wave of data.

SHARE, HRS and ELSA are truly multidisciplinary surveys. Variables include health variables (e.g. self-reported health, physical functioning, cognitive functioning, physical measures such as grip strength and walking speed, health behaviour, use of health care facilities), psy- 
chological variables (e.g. psychological health, well-being, life satisfaction), economic variables (e.g. current work activity, job characteristics, opportunities to work past retirement age, employment history, pension rights, sources and composition of current income, wealth and consumption, housing, education), and social support variables (e.g. assistance within families, transfers of income and assets, social networks, volunteer activities, time use).

SHARE, as opposed to HRS and ELSA, has one additional dimension: it is ex ante harmonized cross-national. The first wave in 2004 involved 11 countries, representing Europe's economic, social, institutional, and cultural diversity from Scandinavia (Denmark, Sweden) across Western and Central Europe (Austria, Germany, France, Belgium, The Netherlands, Switzerland) to the Mediterranean (Greece, Italy, Spain). In 2006, additional data will come from the Czech Republic, Ireland, Israel and Poland. SHARE is the first European data set to combine extensive cross-national information on socio-economics status, health, and family relationships of the elderly population.

At this point, SHARE has collected a first baseline wave of data. A preliminary release of the data contains 22,777 individuals aged 50 and older (including spouses, irrespective of age) in 10 countries; see Table 1 for a detailed breakdown of this sample. We augment this sample by the recent release of the Belgian SHARE data.

Table 1: Sample size and response rate of SHARE and other European surveys

\begin{tabular}{|c|c|c|c|c|c|c|c|c|c|c|}
\hline & \multicolumn{2}{|c|}{ SHARE 2004} & \multicolumn{2}{|c|}{ Eurostat } & \multicolumn{5}{|c|}{ Scientific surveys } & \multirow[b]{2}{*}{$\begin{array}{c}\text { Avg } \\
\cdot \\
\end{array}$} \\
\hline & $\begin{array}{c}\text { Sample } \\
\text { size }\end{array}$ & $\begin{array}{l}\text { Response } \\
\text { rate }\end{array}$ & $\begin{array}{c}\text { ECHP } \\
1994\end{array}$ & $\begin{array}{l}\text { LFS } \\
1996\end{array}$ & $\begin{array}{c}\text { ESS } \\
2002\end{array}$ & $\begin{array}{l}\text { ESS } \\
2004\end{array}$ & $\begin{array}{c}\text { EVS } \\
99-00\end{array}$ & $\begin{array}{l}\text { EES } \\
1999\end{array}$ & $\begin{array}{l}\text { ISSP } \\
2002\end{array}$ & \\
\hline Austria & 1,986 & 58.1 & - & - & - & 62.4 & 77 & 49 & 63.9 & 63.1 \\
\hline Denmark & 1,732 & 63.2 & 62 & 75 & 68 & 65.1 & 57 & 59 & 66.1 & 64.6 \\
\hline France & 1,842 & 73.6 & 79 & (a) & - & - & 42 & 44 & 20.3 & 46.3 \\
\hline Germany & 3,020 & 63.4 & 47 & (a) & 57 & 50.0 & 42 & 49 & 42.7 & 47.9 \\
\hline Greece & 2,142 & 61.4 & (a) & - & 80 & 78.8 & 82 & 28 & - & 67.2 \\
\hline Italy & 2,559 & 55.1 & (a) & - & 44 & - & 68 & - & - & 56.0 \\
\hline Netherlands & 3,000 & 61.3 & (a) & 59 & 68 & - & 40 & 30 & 46.6 & 48.7 \\
\hline Spain & 2,419 & 53.3 & 67 & (a) & 53 & 54.8 & 24 & - & (a) & 49.7 \\
\hline Sweden & 3,067 & 50.2 & - & (a) & 69 & 65.8 & 41 & 31 & 57.2 & 52.8 \\
\hline Switzerland & 1,010 & 37.6 & - & - & 34 & 46.9 & - & - & 32.8 & 37.9 \\
\hline Total* & 22,777 & 61.8 & 62.0 & 63.2 & 55.6 & 54.9 & 46.4 & 43.9 & 36.7 & 50.8 \\
\hline
\end{tabular}

Notes: (a) no pre-screening response rate reported, (-) country not in sample, $\left(^{*}\right)$ weighted average. ECHP: European Community Household Panel; EU-LFS: European Labour Force Survey; ESS: European Social Survey; EVS: European Values Study; EES: European Election Study; ISSP: International Social Survey Project. Source: De Luca and Peracchi (2005). 
SHARE compares favorably to the other surveys, although the weighted average $(62 \%$, unweighted $60 \%$ ) is still lower than what is typically seen in the US. The appropriate comparison is probably with the newest HRS cohort (the Early Baby Boomers cohort drawn in 2004) which has a response rate at baseline of $69 \%$. Earlier, the HRS has experienced much higher, but declining response rates. For the initial cohort of HRS in 1992, a response rate of $82 \%$ could be achieved, while the samples drawn in 1998 had a response rates of 70 percent. There is no directly comparable response rate of ELSA, the English Longitudinal Study on Ageing, which is very close in contents to SHARE, since the sample of ELSA was based on those who were successfully interviewed in the Health Survey of England. The response rate was lowest in Switzerland, which is typical for this country, and highest in France, where the national statistical office INSEE conducted the survey.

Unit non-response was compensated by adjusting the design weights. This was done in a calibration approach. In most countries the calibration was done to national population totals decomposed by age and gender, in two countries more information could be used and in two countries just national totals by gender were used.

SHARE has made great efforts to deliver truly comparable data, so we can reliably study how differences in cultures, living conditions and policy approaches shape the life of Europeans just before and after retirement. The questionnaire has been translated according to a protocol ensuring functional equivalence and was administered by a Computer Assisted Personal Interview (CAPI) plus a drop off self completion part. Interview procedures have been harmonized with the help of a joint case management system. Methodological details of the study are contained in Börsch-Supan and Jürges (2005), and first results summarized in BörschSupan et al. (2005). The SHARE data is available at http://www.share-project.org. Further data processing and record matching are still going on. A final release is expected in late 2006 with more than 30,000 individuals.

This paper is based on an extract of variables which include whether a person receives disability insurance or not; basic demographic characteristics, and a broad set of health variables. These health variables include self-reported health, functional status measured by indicators of (instrumental) activities of daily living, a set of mental health questions (e.g., CES-D) indicating dementia and depression, and physical measurements such as body mass index, walking speed and grip strength. Most variables are identical in all three surveys. Weight and height (to compute body mass index) are self-reported in HRS and SHARE, while actually measured in ELSA. Grip strength is only available in SHARE. 
Disability insurance is defined as all branches of publicly financed insurances against the loss of the ability to perform gainful employment. Table 2 lists the institutions in each country:

Table 2: Disability insurance schemes considered

\begin{tabular}{|c|c|}
\hline Austria (AT) & Staatliche Invaliditätspension \\
\hline Belgium (BE) & $\begin{array}{l}\text { Assurance invalidité légale/Wettelijke uitkering wegens arbeidsongeval of beroeps- } \\
\text { ziekte; Pension de maladie, d'invalidité, maladie professionnelle/Wettelijke uitkering } \\
\text { wegens ziekte of invaliditeit of tegemoetkoming aan personen met een handicap }\end{array}$ \\
\hline Switzerland $(\mathrm{CH})$ & Invalidenrente aus IV, assurance invalidité légale (AI) and Rendità invalidità (AI) \\
\hline Germany (DE) & Erwerbsminderungsrente and Beamtenpension wegen Dienstunfähigkeit \\
\hline Denmark (DK) & Offentlig sygedagpenge and offentlig førtidspension \\
\hline Spain (ES) & Pensión pública contributiva y no contributiva de invalidez/incapacidad \\
\hline France (FR) & Prestation publique d'invalidité (AAH, APA) \\
\hline Greece (GR) & $\Sigma v ́ v \tau \alpha \xi \eta \alpha v \alpha \pi \eta \rho i ́ \alpha \varsigma$ \\
\hline Italy (IT) & $\begin{array}{l}\text { Assicurazione pubblica di disabilità (anche assegno di accompagnamento)" and } \\
\text { pnsione pubblica di invalidità o di inabilità }\end{array}$ \\
\hline Netherlands (NL) & $\begin{array}{l}\text { WAO, Waz of invaliditeitspensioen and Algemene bijstandswet (Abw), } \\
\text { IOAW/IOAZ, aanvullende bijstandsuitkering, Toeslagenwet (TW) }\end{array}$ \\
\hline Sweden (SE) & Förtidspension (sjukersättning), yrkesskadepension, and sjukbidrag \\
\hline England (UK) & Incapacity benefits (previously invalidity benefits) \\
\hline United States (US) & SSDI and SSI disability pension \\
\hline
\end{tabular}

We restrict our analysis to individuals in the "window" from age 50 to age 65 in which disability insurance may serve as an early retirement device. SHARE covers 11 countries with 15808 individuals of this age. ELSA and HRS contribute 6732 and 4270 individuals, respectively, to the joint sample, thus consisting of 26810 individuals. For joint descriptive statistics, the calibrated weights have been re-normalized to give each country equal weight. 
Figure 5: Disability insurance enrolment by age

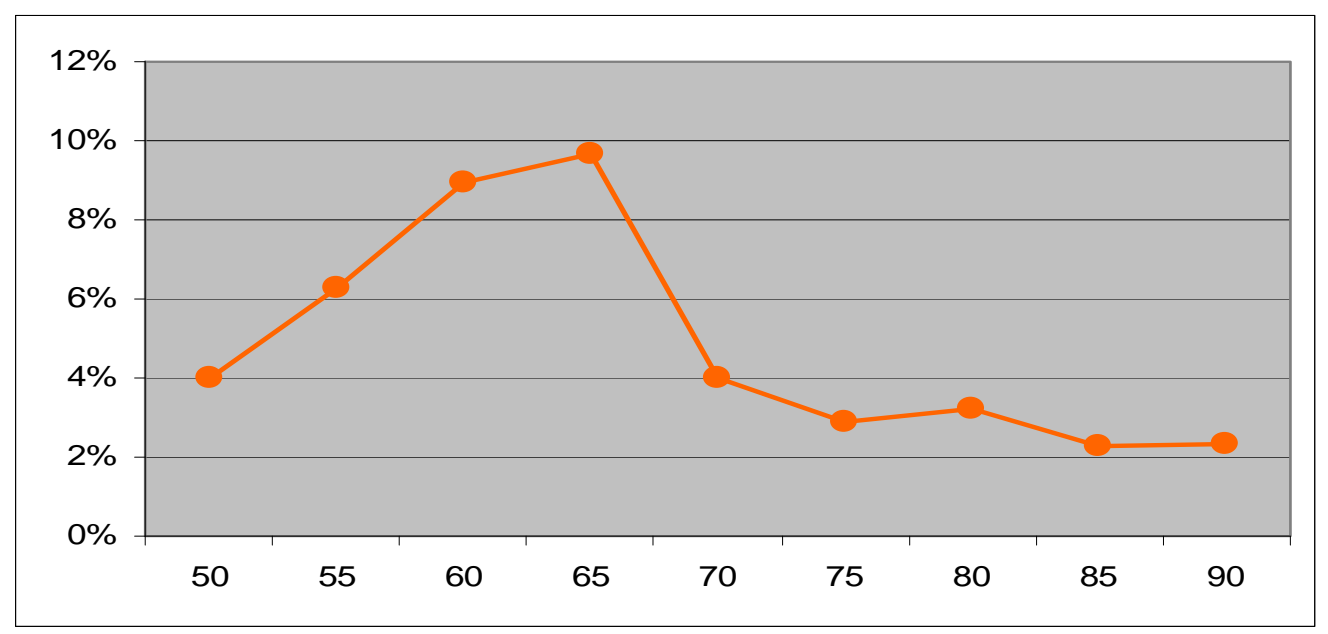

Note: Percentage of individuals enrolled in disability insurance by age.

Enrolment rises steeply from 4\% on average across all SHARE countries at age 50 to almost $10 \%$ at age 65 , see Figure 5 . In most countries, disability insurance benefits are automatically converted to old-age pension benefits at age 65. Disability insurance enrolment rates therefore decline after age 65 to percentages lower than at age 50 .

Our finding of a striking variation across European countries in the number of persons who receive disability insurance benefits is echoed in the micro data, see Figure 6.

Figure 6: Disability insurance enrolment in Europe, 2004

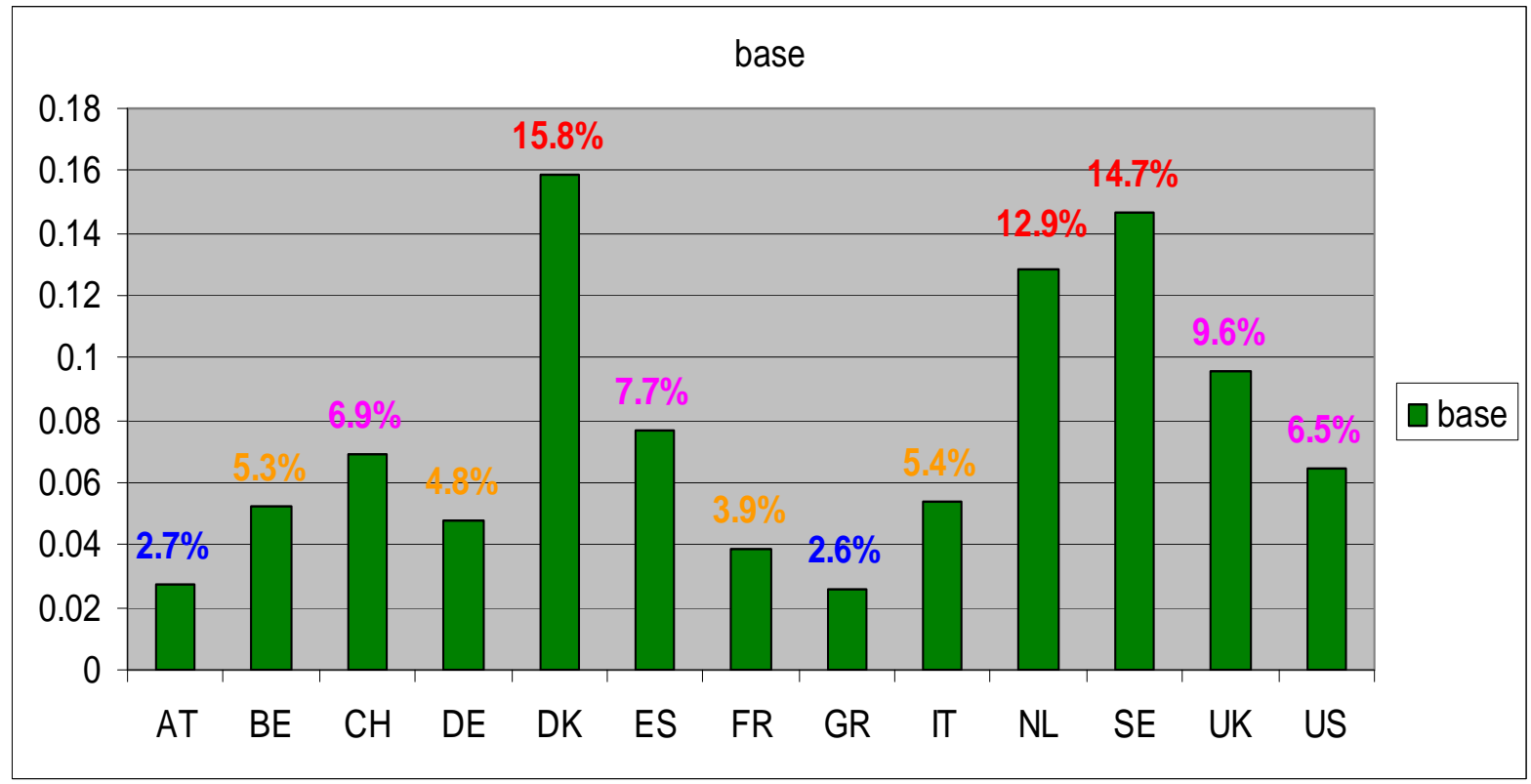

Note: Based on 26810 individuals aged 50 through 65 interviewed in SHARE 2004, ELSA 2002 and HRS 2004. Weighted data. 
We can distinguish four country groups. Very high enrolment rates exist in Denmark, the Netherlands and Sweden. Between 13 and 16 percent of individuals aged between 50 and 65 receive disability insurance benefits in this first group of countries. The second group has enrolment rates around the average enrolment rate of $7.5 \%$. This group consists of Switzerland, Spain, the UK and the US, with the UK substantially above this average. Here the enrolment ranges from 6 to almost 10 percent. Belgium, Germany, France and Italy, the third group, have below average enrolment rates between 4 and 6 percent. In Austria and Greece less than 3 percent of individuals aged between 50 and 65 receive disability insurance benefits.

\section{Regression results}

Our aim is to look which weight each of the three potential causes -- demographics, health and institutions -- has in explaining disability enrolment in Europe. Our strategy is straightforward. We exploit the richness of the SHARE, ELSA and HRS data to first relate individual disability insurance enrolment probabilities to three types of variables:

- demographic characteristics (age and gender)

- a broad set of health measures, ranging from self-reported health to more objective measurements of the functional physical and mental health status (ADL, IADL and CES-D)

- a set of variables characterizing the generosity of the disability insurance in each country (coverage, minimum disability level required, benefit generosity, medical assessment, vocational assessment). These variables are taken from OECD (2003), Appendix A2.3.

We then predict how enrolment rates would look like if demographics were equal across countries. If demographic differences were the main cause, enrolment rates should be very similar after taking demographic differences out. We then go through the same procedure for differences in health status. If enrolment rates are still very different after accounting for demographic and health differences, the third explanation - differences in the institutional regulations - is a likely cause.

We run three regressions: a simple linear model for the probability to become enrolled into disability, a probit specification, and a logit specification. Table 3 presents the results. A first finding is the similarity among the three specifications. A second observation is the large unexplained variation. This is in line with the findings of OECD (2003) where only little correlation between "medical disability status" and "disability enrolment status" was found. 
Demographic variables are jointly significant. Women have a lower probability to enrol into disability insurance, conditional on health. Also this was a finding of OECD (2003). Older age increases to probability to be enrolled, and this more than linearly, as can be seen by the dummy specification.

All health variables are strongly significant. Since we do not have grip strength and walking speed in all three surveys, these variables are not included. Including them in the SHARE sample reduces the significance of the self-reported health measure considerably, but leaves the overall results unaffected. Noteworthy is the significant effect of mental illness, measured by the CES-D battery, conditional on physical health.

Finally, the incentive variables are also highly significant. Increased coverage (which population groups are eligible for insurance - workers only, or the entire population) increases disability enrolment, as does a lenient minimum disability level to claim benefits. The generosity of benefits is significant, but with an unexpected negative sign. The strictness of a medical exam reduces disability uptake. If vocational considerations play a role in the eligibility process, then their strictness also reduces uptake.

Table 3: Regression results

\begin{tabular}{lcccccc}
\hline Variable & Linear & t-stat & Probit & t-stat & Logit & t-stat \\
\hline Gender & -0.0242 & -6.2 & -0.1696 & -5.6 & -0.3228 & -5.5 \\
Age & 0.0007 & 0.5 & 0.0072 & 0.7 & 0.0131 & 0.6 \\
Age_50 & 0.0166 & 0.6 & 0.1148 & 0.5 & 0.1789 & 0.4 \\
Age_55 & 0.0076 & 0.4 & 0.0406 & 0.3 & 0.0906 & 0.3 \\
Age_60 & 0.0152 & 1.1 & 0.1016 & 1.0 & 0.1947 & 1.0 \\
Age_65 & 0.0197 & 2.2 & 0.1438 & 2.1 & 0.2773 & 2.1 \\
\hline Self-reported health & 0.0563 & 29.0 & 0.4301 & 27.4 & 0.8579 & 27.4 \\
CES-D (Sum) & 0.0153 & 9.5 & 0.0791 & 7.2 & 0.1465 & 7.1 \\
ADL (Sum) & 0.0445 & 13.2 & 0.1381 & 7.5 & 0.2197 & 6.7 \\
IADL (Sum) & 0.0364 & 8.0 & 0.1145 & 4.6 & 0.1907 & 4.2 \\
\hline Coverage & 0.0467 & 11.2 & 0.3426 & 10.6 & 0.6583 & 10.5 \\
Minimum disability level & 0.0149 & 7.4 & 0.1154 & 6.5 & 0.2317 & 6.4 \\
Benefit generosity & -0.0180 & -7.3 & -0.1648 & -8.3 & -0.3115 & -7.9 \\
Medical assessment & -0.0088 & -3.7 & -0.0849 & -4.6 & -0.1587 & -4.4 \\
Vocational assessment & -0.0136 & -4.7 & -0.1591 & -6.4 & -0.3266 & -6.6 \\
\hline Constant & -0.2255 & -2.4 & -3.6933 & -5.1 & -6.9566 & -5.0 \\
R-squared & & $13.1 \%$ & & $19.9 \%$ & & $19.8 \%$ \\
\hline
\end{tabular}

Note: Based on 18434 individuals aged 50 through 65 interviewed in SHARE 2004, ELSA 2002 and HRS 2004. 


\section{Counterfactual simulations}

Our first step is to normalize disability insurance enrolment with respect to demographic differences across countries. Italy, for instance, has an older population than the European average, while Denmark has a younger population. We take out demographic differences by first establishing the influence of age and gender on disability insurance take up. We then predict which share of our sample individuals would take up disability insurance if all countries had the same age and gender distribution as the average of the SHARE countries. The result is shown in Figure 7, comparing the counterfactual simulation results to the baseline results from Figure 6.

Figure 7: Actual and predicted disability insurance enrolment if age and gender were identical in all countries

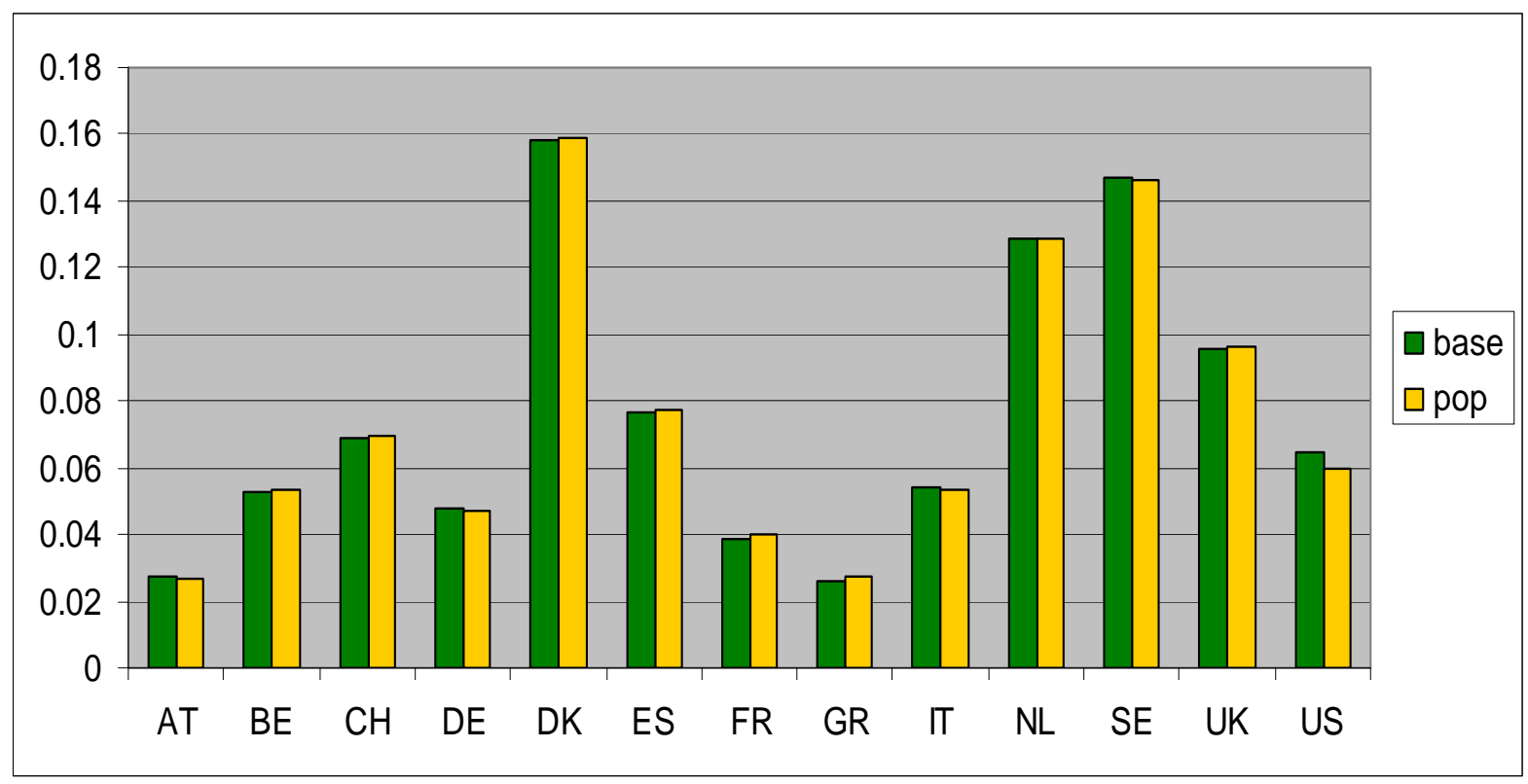

Note: Based on linear regression specification in Table 3.

Quite clearly, taking account of demographic differences does not make a substantive difference. Italy, featuring the highest average age of individuals aged between 50 and 65 years among the 13 countries, would have a slightly lower disability insurance enrolment if it had the age distribution of the average country. In Denmark, which is younger than average, the opposite would happen. The effects, however, are very small. Demographic differences across Europe cannot explain why the enrolment rates in disability insurance are so different in Europe. 
Our second step is therefore to account for difference in the health status of the population. The health status differs along many dimensions across countries. A first dimension is selfassessed health. Self-assessed health is relatively poor in Italy and Spain, it is best in Switzerland. One major concern with the self-assessed health ratings, however, is that respondents do not perceive the health self-assessment scale given to them as absolute. Individuals with the same true health status may have different reference levels against which they judge their health. This sheds doubt on the comparability of such measures across countries (e.g., Groot 2000; Sen 2002). We therefore also include more objective measures such as the physical performance in daily activities such as walking or bathing. In this second dimension, Germany exhibits the most limitations and Greece the least. A third dimension is mental health. Depression, an often named reason for taking up disability insurance, varies quite substantially across the SHARE countries. Spain, Italy and France show the worst scores on the CES-D depression scale, while Denmark, Germany and Switzerland have the lowest share of depression cases. Hence, the cross-national variation in health status looks like a good candidate to explain the variation in disability insurance enrolment.

We use the same methodology to correct for the influence of the multidimensional health differences as we did with demographics. We first establish the influence of health on disability insurance take up, and then predict which share of our sample individuals would take up disability insurance if the health status measured along the above four dimensions would be identical to the average of our 13 countries. The results are shown in Figure 8. 
Figure 8: Predicted disability insurance enrolment if health status were identical

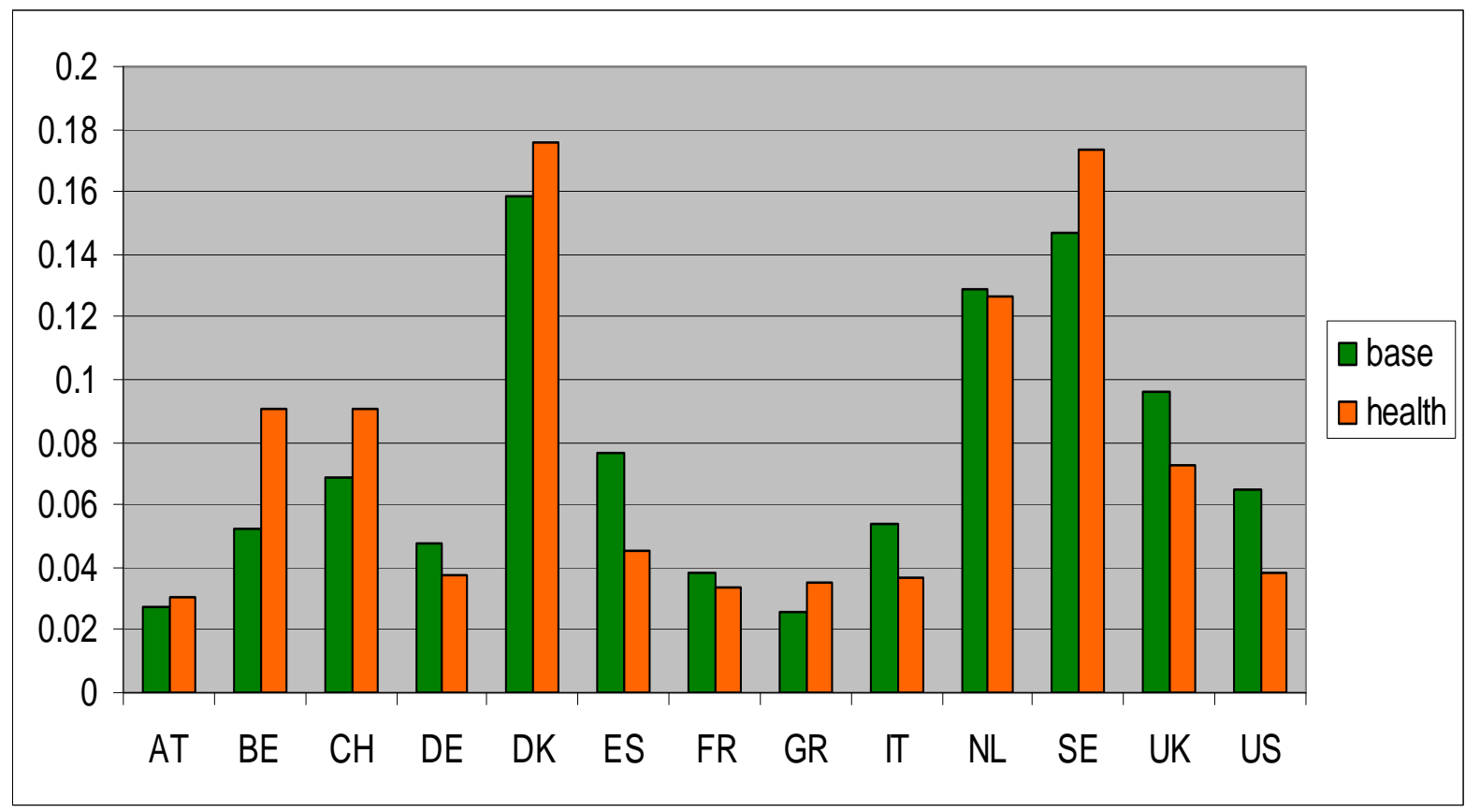

Note: Based on linear regression specification in Table 3.

The differences between enrolment rates under the actual and a hypothetically identical health status are now more pronounced. In general, the counterfactual enrolment rates go up in countries with good health, and down in countries with lower health status than the average, as expected. If the Italians and Spaniards had the same health status as the average person in our sample, their disability insurance enrolment would be much lower. The same holds, notably, for the two Anglo-Saxon countries. In Switzerland, Denmark and Sweden, it would be considerably higher.

If health would be the dominant explanation for disability insurance enrolment, the predicted shares should be equal across countries, once health is identical in all countries. As Figure 8 shows, this is clearly not the case. There are still pronounced differences. Especially the high enrolment rates in Sweden, Denmark and the Netherlands remain either relatively stable after correcting for health differences (Netherlands), or they increase even further (Sweden and Denmark). We conclude that differences in health across Europe cannot explain the crossnational variation in the European disability insurance enrolment; just the opposite: in Sweden and Denmark enrolment rates are high in spite of a very good health status of the 50-65 year olds in our sample.

A logical next step is to correct for differences in demographics and health simultaneously, using the same methodology as before. Figure 9 shows the results. 
Figure 9: Predicted disability insurance enrolment if age, gender and health status were identical in all countries

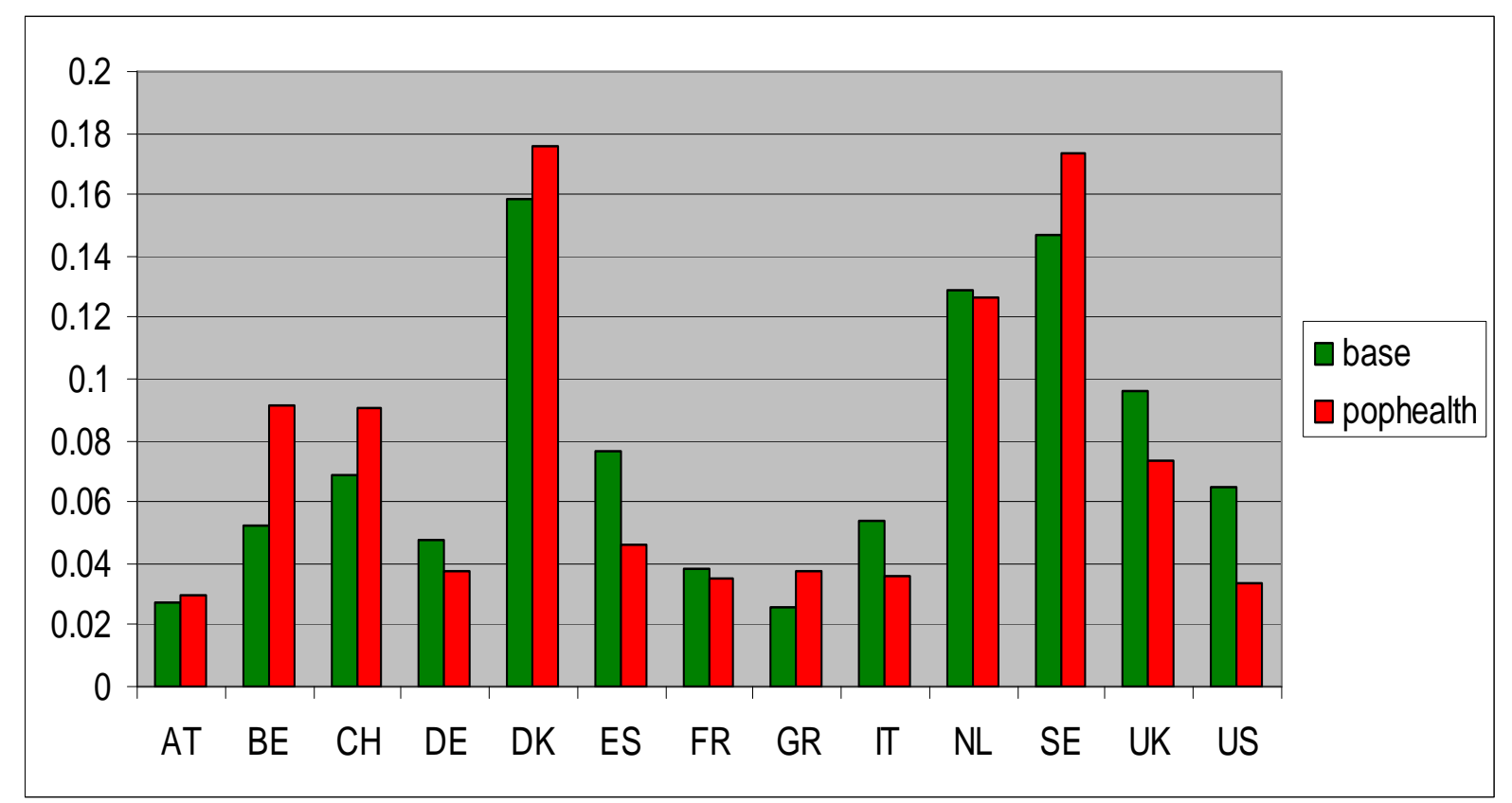

Note: Based on linear regression specification in Table 3.

The picture changes only slightly from the last one. Hence, counterfactually making all countries have an identical age, gender and health distribution does not make the striking variation in the uptake of disability insurance across the 13 countries vanish. Especially the large enrolment rates in Sweden, Denmark and the Netherlands must have different reasons than an older population or a worse health status in these countries.

Which reasons could it be? By exclusion of the first two of the three popular explanations -demographic and health-related differences -- the third popular explanation remains, namely institutional differences, specifically enrolment and eligibility rules that make disability insurance benefits easier to receive and more generous in some countries than in others. Such rules may create incentive effects similar to those exerted by old-age pensions which often provide a financial incentive to retire early. In many countries, health requirements for disability insurance eligibility are weak. Under such circumstances, disability insurance may work as a labour market exit route to early retirement (Börsch-Supan 2001). Many countries have established very lenient work disability eligibility rules under the conditions of high unemployment.

The final step of our argument would therefore be to conduct a third counterfactual analysis which makes disability eligibility rules identical for all individuals in our cross-national sam- 
ple and then predict the take-up outcomes in the same sprit as Figures 7 through 9. While a complete capture of the entire complex set of eligibility and benefit rules is probably impossible to model, we employ five indicators provided by OECD (2005), measuring the coverage of disability insurance, the minimum disability level required to obtain benefits, the benefit generosity, how strict a medical assessment is applied, and whether vocational considerations play a role. We have seen that these variables are highly significant in the regression analysis, see Table 3. Using the same methodology as before, Figure 10 shows counterfactual uptake rates if these system characteristics were identical in all 13 countries of our cross-national sample.

The results are striking. The counterfactual simulation holding eligibility and benefit generosity rules approximately constant produces much more similar disability uptake rates than holding demographics and health constant. The only outlier is Switzerland, where uptake rates would be extremely low under average generosity.

Figure 10: Predicted disability insurance enrolment if eligibility and benefit rules were equally generous in all countries

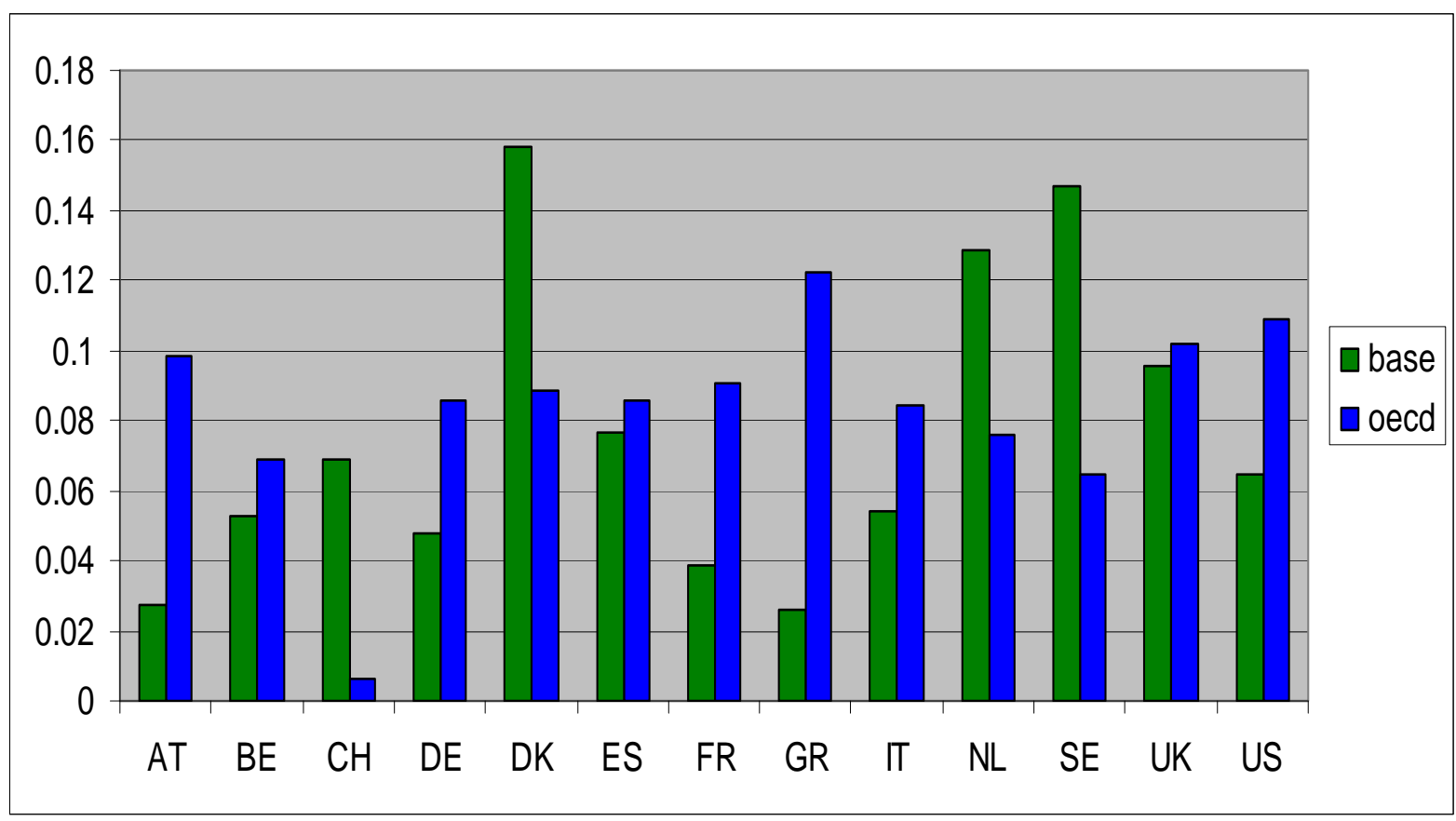

Note: Based on linear regression specification in Table 3.

A simple "back-of-the-envelope" regression confirms the above results. Regressing the aggregate enrolment rates in the small sample of 13 countries on the above five indicator variables yields an R-squared of $89 \%$ (adjusted $78 \%$ ) and highly significant coefficients. Hence, 
almost 90 percent of the cross-national variation in enrolment rates can be explained by the institutional factors embedded in the five OECD indicators. As a matter of fact, the most influential variable is the strictness by which vocational considerations, if any, are applied. This is clearly seen in Figure 11. Regressing the national enrolment rates on this variable alone explains more than $60 \%$ of the cross-national variation.

Figure 11: Disability insurance enrolment rates and strictness of vocational assessment

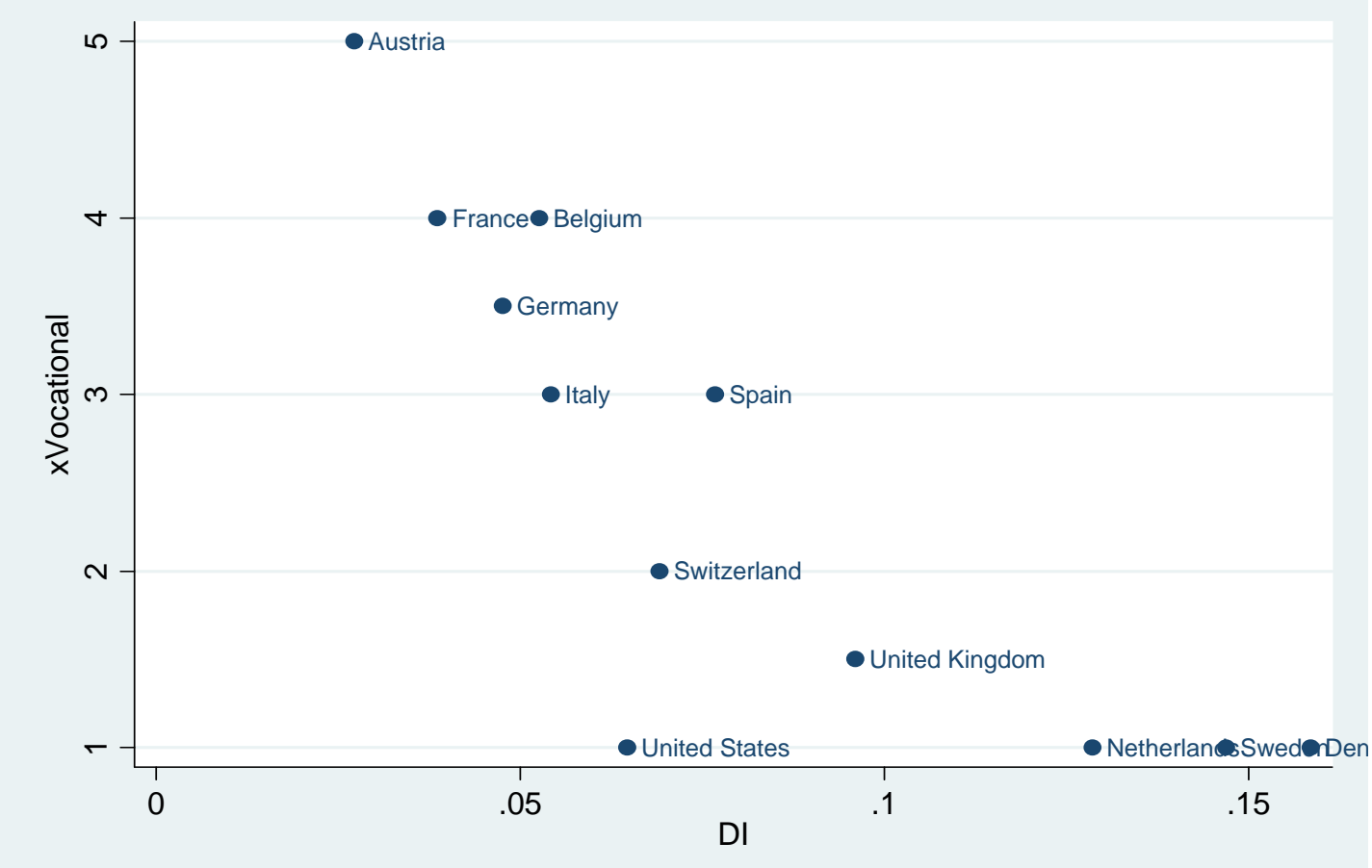

\section{Summary and conclusions}

Figure 12 summarizes our results in a single chart.

The variation in disability insurance take-up rates across European countries is striking. It reaches from some 15 percent of individuals aged between 50 and 65 in Denmark, Sweden and the Netherlands to less than 3 percent in Austria and Greece. 
Figure 12: Baseline enrolment rates and counterfactual simulations

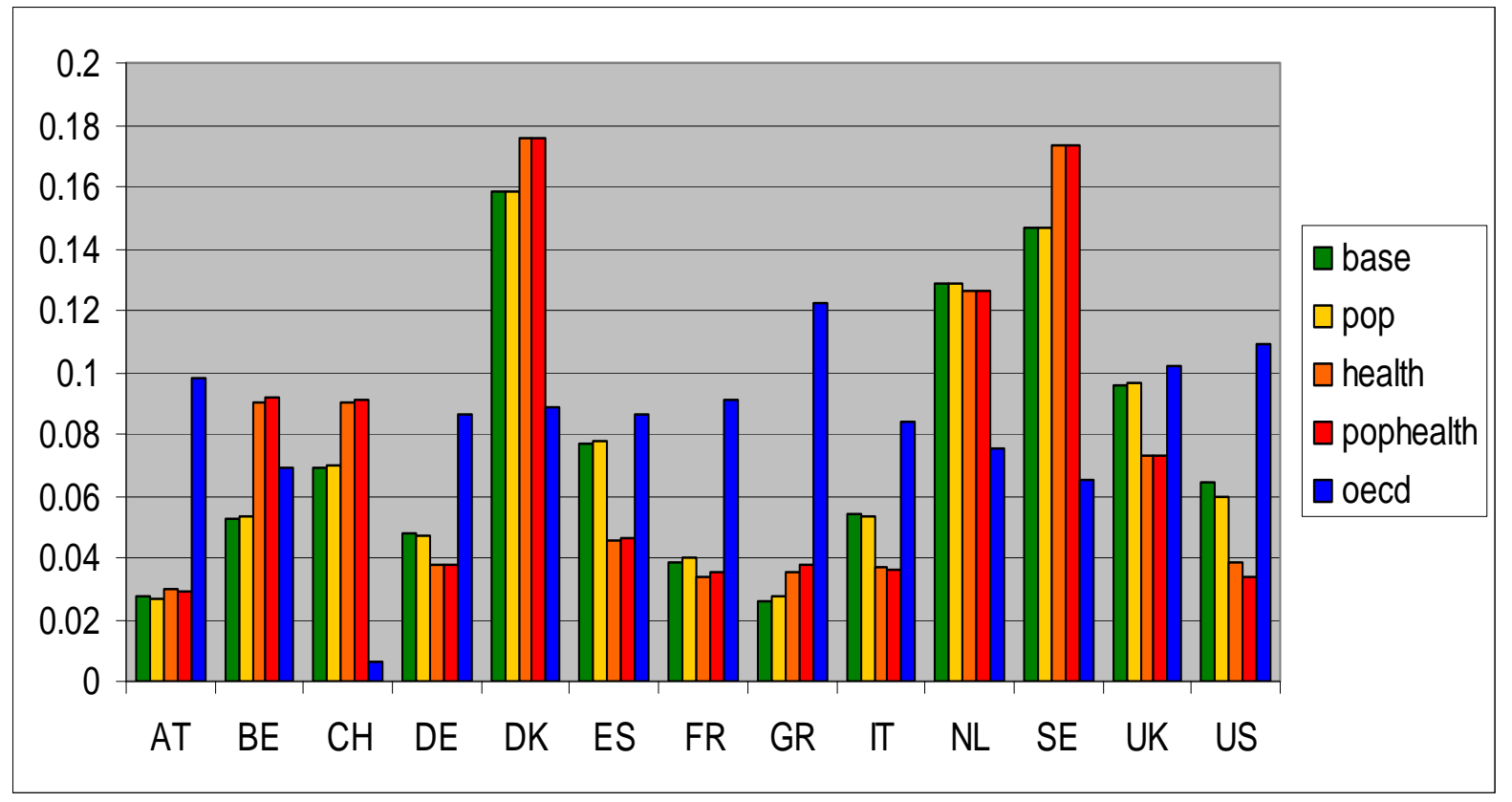

Note: Based on linear regression specification in Table 3.

Correcting for differences in the age, gender and health distribution across countries does not explain this striking variation. Especially the large enrolment rates in Sweden, Denmark and the Netherlands have different reasons than an older population or a worse health status than in the other European countries.

Institutional factors - incentives created by enrolment and eligibility rules - are a more likely explanation. A counterfactual simulation holding eligibility and benefit generosity rules approximately constant produces much more similar disability uptake rates than holding demographics and health constant.

The most influential variable is the strictness by which vocational considerations, if any, are applied. This variable alone explains more than $60 \%$ of the cross-national variation. It seems to be the most powerful policy variable when countries such as the Netherlands, Denmark and Sweden want to bring their disability insurance enrolment rates closer to the average European and US level.

In June 2007, data from wave 2 of SHARE will be available. This will add more variation to the country-level data. 


\section{References}

Aarts LJM, Burkhauser RV, de Jong PR (eds) (1996) Curing the Dutch disease. An international perspective on disability policy reform. Aldershot, Avebury.

Banks, J., A. Kapteyn, J.P. Smith, A. van Soest. (2004), International Comparisons of Work Disability, RAND Working Paper, WR-155.

Bardage C, Plujim SMF, Pedersen NL, Deeg DJH, Jylhä M, Noale M, Blumstein T, Otero A (2005) Self-rated health among older adults: a cross-national comparison. European Journal of Ageing 2: 149-158.

Blöndal, S. and S. Scarpetta (1998), The retirement decision in OECD countries, OECD Economics Department Working Paper.

Börsch-Supan A (2001) Incentive effects of social security under an uncertain disability option. In: Wise DA (ed) Themes in the economics of aging. University of Chicago Press, Chicago, pp. 281-310.

Börsch-Supan A (2004) Global aging: Issues, answers, more questions. MEA Discussion Paper 552004, University of Mannheim.

Börsch-Supan A, Brugiavini A, Jürges H, Mackenbach J, Siegrist J, Weber G (eds) (2005) Health, ageing and retirement in Europe - First results from the Survey of Health, Ageing and Retirement in Europe. Mannheim Research Institute for the Economics of Aging, Mannheim.

Börsch-Supan A, Jürges J (eds) (2005) The Survey of Health, Ageing and Retirement in Europe Methodology. Mannheim Research Institute for the Economics of Ageing, Mannheim, forthcoming.

Börsch-Supan, A., (2005), Work disability and health, in: Börsch-Supan et al. (eds.) Health, Ageing and Retirement in Europe. First Results from SHARE, MEA: Mannheim.

De Luca, G. and F. Peracchi (2005), Survey Participation in the First Wave of SHARE in: BörschSupan, A., and H. Jürges (eds.) Health, Ageing and Retirement in Europe: Methodology, MEA: Mannheim.

Dewey ME, Prince MJ (2005) Mental health. In Börsch-Supan A, et al. (eds) Health, ageing and retirement in Europe - First results from the Survey of Health, Ageing and Retirement in Europe. Mannheim Research Institute for the Economics of Aging, Mannheim, pp. 108-117.

European Commission (2004), Adequate and sustainable pensions, Joint report by the Commission and the Council.

Groot W (2000) Adaption and scale of reference bias in self-assessments of quality of life. Journal of Health Economics 19: 403-420.

Gruber JD, Wise DA (1999). Social Security and Retirement around the World, The University of Chicago Press: Chicago.

Gruber, J., and D. Wise (eds.) (2004), Social Security and Retirement Around the World: Micro Estimation of Early Retirement Incentives, University of Chicago Press.

Gruber, J., and D. Wise (eds.) (2005), Social Security and Retirement Around the World: Budget Impacts of Early Retirement Incentives, University of Chicago Press.

Hayward MD, Zhang Z (2001) Demography of aging. In: Binstock RH, George LK (eds) Handbook of aging and the social sciences ( ${ }^{\text {th }}$ ed.). Academic Press, San Diego, pp. 69-85.

Jürges, Hendrik (2005), Cross-Country Differences in General Health in: Börsch-Supan et al. (eds.) Health, Ageing and Retirement in Europe. First Results from SHARE, MEA: Mannheim.

Juster FT, Suzman R (1995) An overview of the Health and Retirement Study. Journal of Human Resources 30 (Special Issue): S7-S56. 
Kapteyn, A., J.P. Smith, and A. van Soest (2004), Self-reported Work Disability in the US and The Netherlands, RAND Working Paper WR-206.

King, G., C. Murray, J. Salomon and A. Tandon (2004), Enhancing the validity and cross-cultural comparability of measurement in survey research, American Political Science Review, 98(1), 567-583.

Kohli M, Rein M, Guillemard A-M, van Gunsteren H (eds) (1991) Time for retirement: Comparative studies of early exit from the labor force. Cambridge University Press, Cambridge.

Lan, T.Y., D.J.H. Deeg, J.M. Guralnik, and D. Melzer (2003), Responsiveness of the index of mobility limitation: comparison with gait speed alone in the longitudinal aging study Amsterdam, Journal of Gerontology: Medical Science, 58A, 721-728.

Mackenbach, J., M. Avendano, K. Andersen-Ranberg, and A.R. Aro (2005), Physical Health, in: Börsch-Supan et al. (eds.) Health, Ageing and Retirement in Europe. First Results from SHARE, MEA: Mannheim.

Marmot, M., J. Banks, R. Blundell, C. Lessof, and J. Nazroo (2003): Health, Wealth and Lifestyles of the Older Population in England: The 2002 English Longitudinal Study of Ageing. London: The Institute for Fiscal Studies.

National Research Council (2001), Preparing for an Aging World: The Case for Cross-National Research, Panel on a Research Agenda and New Data for an Aging World, Committee on Population and Committee on National Statistics, Division of Behavioral and Social Sciences and Education. Washington, DC: National Academy Press.

OECD (2003), Transforming Disability into Ability, Paris.

OECD (2005), OECD Health Data, Paris.

Sen A (2002) Health perception versus observation. British Medical Journal 324: 860-861.

WHO (2002) Active ageing: A policy framework. World Health Organization, Geneva. 


\section{Appendix: OECD 2003 Tables and Definitions}

Disability benefit recipiency rates in 1999 by benefit programme, percentage of 20-64 population, late 1990s

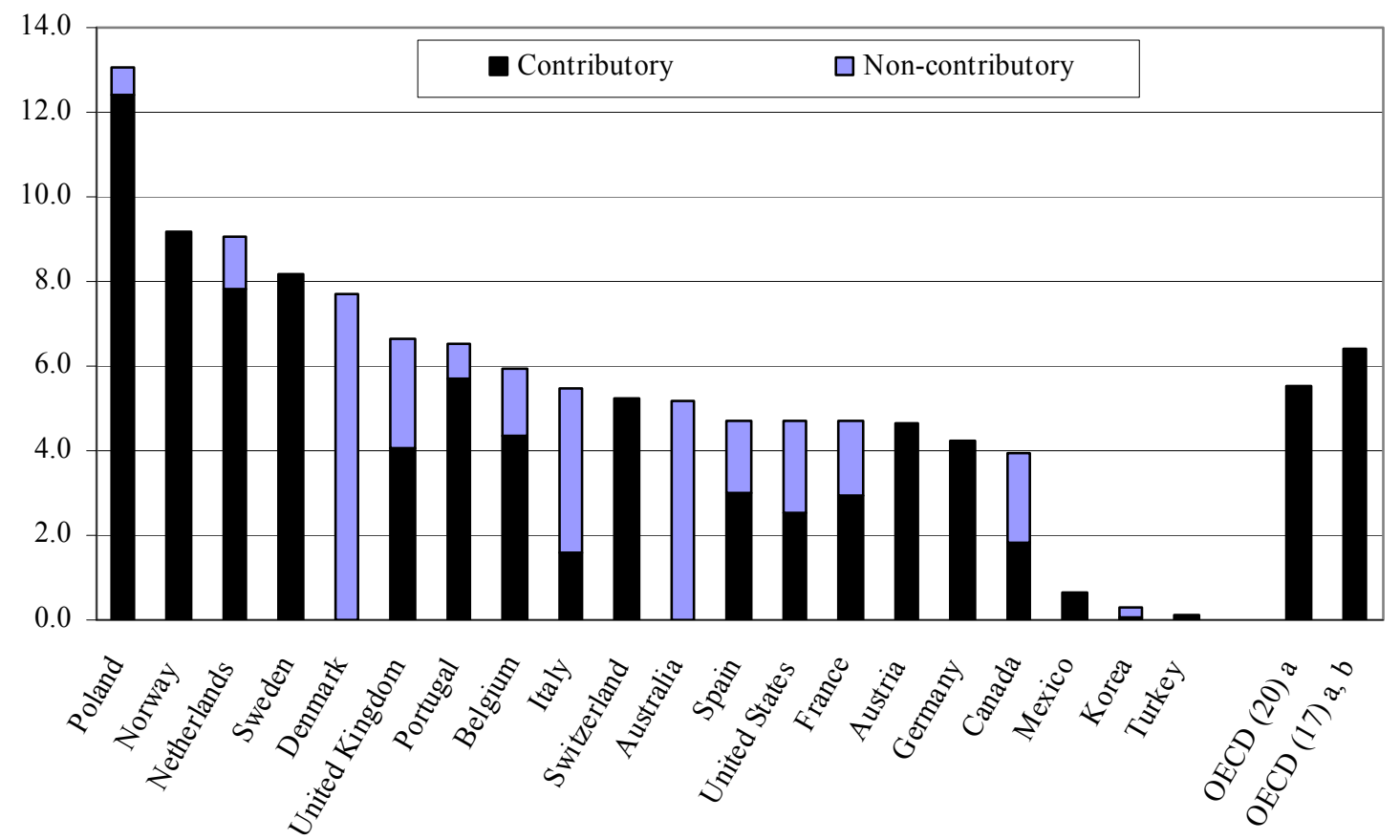

Note: The rate is corrected for persons receiving both contributory and non-contributory benefits, except for Canada (unknown).

a) Contributory and non-contributory benefits.

b) Excluding Mexico, Korea and Turkey.

Source: OECD database on programmes for disabled persons, see Annex 1, Table A1.2. 
Table 2.1 Considerable variation in public expenditure on disability-related programmes ${ }^{a}$

Disability programme expenditure in percentage of GDP

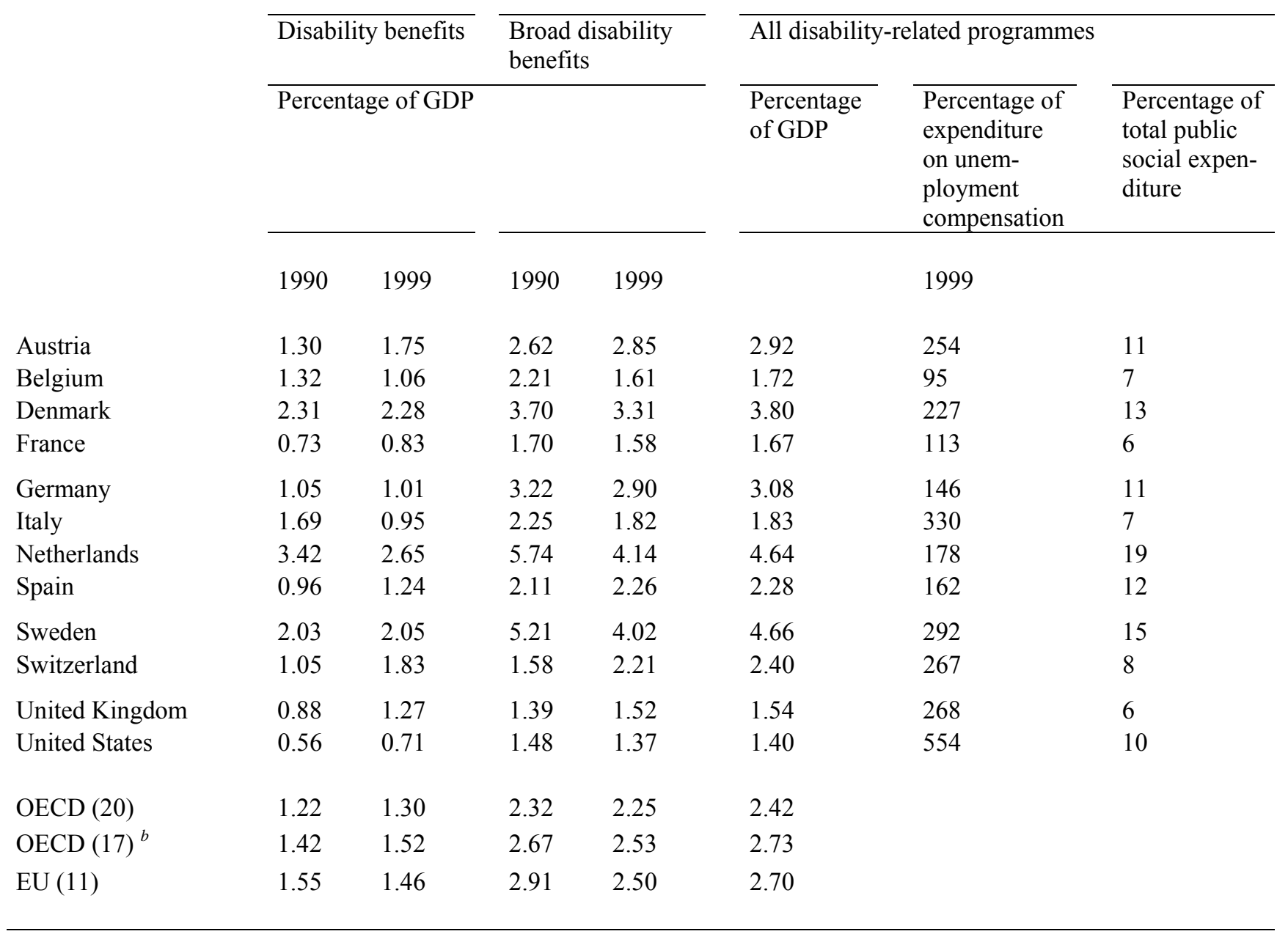

a) Various definitions of disability benefits are as follows:

Disability benefits $=$ Contributory (earnings-related) and non-contributory disability benefits.

Broad disability benefits = Disability benefits, sickness cash benefits and work injury benefits.

All disability programmes = Broad disability benefits and employment-related programmes for disabled people .

Note: Sickness cash benefits include mandatory private benefits, i.e. continued wage payment.

b) Excludes Korea, Mexico and Turkey.

Source: See Annex 1, Table A1.1; OECD (2001c). 
Table A2.1. Classification for the compensation dimension of the policy typology

\begin{tabular}{|c|c|c|c|c|c|c|}
\hline Dimension & 5 points & 4 points & 3 points & 2 points & 1 point & 0 point \\
\hline \multicolumn{7}{|l|}{ X. Compensation } \\
\hline x1. Coverage & total population (residents) & $\begin{array}{l}\text { some of those out } \\
\text { of the labour force } \\
\text { (e.g. congentital) }\end{array}$ & $\begin{array}{l}\text { labour force plus means- } \\
\text { tested non-contrib. scheme }\end{array}$ & $\begin{array}{l}\text { labour force with voluntary } \\
\text { self-insurance }\end{array}$ & labour force & employees \\
\hline x2. Minimum disability level & $0-25 \%$ & $26-40 \%$ & $41-55 \%$ & $56-70 \%$ & $71-85 \%$ & $86-100 \%$ \\
\hline $\begin{array}{l}\text { x. Disability level for full } \\
\text { benefit }\end{array}$ & $<50 \%$ & $50-61 \%$ & $62-73 \%$ & $74-85 \%$ & $86-99 \%$ & $100 \%$ \\
\hline x4. Maximum benefit level & $\begin{array}{l}\mathrm{RR}>=75 \% \text {, } \\
\text { reasonable minimum }\end{array}$ & $\begin{array}{l}\mathrm{RR}>=75 \%, \\
\text { minimum not specified }\end{array}$ & $\begin{array}{l}75>R R>=50 \%, \\
\text { reasonable minimum }\end{array}$ & $\begin{array}{l}75>R R>=50 \% \text {, minimum } \\
\text { not specified }\end{array}$ & $\begin{array}{l}\mathrm{RR}<50 \% \text {, reasonable } \\
\text { minimum }\end{array}$ & $\begin{array}{l}\text { RR }<50 \% \text {, minimum not } \\
\text { specified }\end{array}$ \\
\hline$x 5$. Permanence of benefits & strictly permanent & de facto permanent & self-reported review only & regulated review procedure & $\begin{array}{l}\text { strictly temporary, unless } \\
\text { fully }(=100 \%) \text { disabled }\end{array}$ & $\begin{array}{l}\text { strictly temporary in all } \\
\text { cases }\end{array}$ \\
\hline x6. Medical assessment & treating doctor exclusively & $\begin{array}{l}\text { treating doctor } \\
\text { predominantly }\end{array}$ & $\begin{array}{l}\text { insurance doctor } \\
\text { predominantly }\end{array}$ & insurance doctor exclusively & $\begin{array}{l}\text { team of experts } \\
\text { in the insurance }\end{array}$ & $\begin{array}{l}\text { insurance team } \\
\text { and two-step procedure }\end{array}$ \\
\hline x7. Vocational assessment & $\begin{array}{l}\text { strict own or usual } \\
\text { occupation assessment }\end{array}$ & $\begin{array}{l}\text { reference is made to one's } \\
\text { previous eamings }\end{array}$ & $\begin{array}{l}\text { own-occupation } \\
\text { assessment for partial } \\
\text { benefits }\end{array}$ & $\begin{array}{l}\text { current labour market } \\
\text { conditions are taken into } \\
\text { acoount }\end{array}$ & $\begin{array}{l}\text { all jobs available taken into } \\
\text { account, leniently applied }\end{array}$ & $\begin{array}{l}\text { all jobs available taken into } \\
\text { account, strictly applied }\end{array}$ \\
\hline x8. Sickness benefit level & $\begin{array}{l}\mathrm{RR}=100 \% \text { also for } \\
\text { long-term sickness absence }\end{array}$ & $\begin{array}{l}\mathrm{RR}=100 \% \text { (short-term) } \\
>=75 \% \text { (long-term) } \\
\text { sickness absence }\end{array}$ & $\begin{array}{l}\text { RR }>=75 \% \text { ( short-term) } \\
>=50 \% \text { (long-term) } \\
\text { sickness absence }\end{array}$ & $\begin{array}{l}75>R R>=50 \% \text { for any } \\
\text { type of sickness absence }\end{array}$ & $\begin{array}{l}\text { RR }>=50 \% \text { (short-term) } \\
<50 \% \text { (long-term) sickness } \\
\text { absence }\end{array}$ & $\begin{array}{l}\mathrm{RR}<50 \% \text { also for short- } \\
\text { term sickness absence }\end{array}$ \\
\hline $\begin{array}{l}\text { x9. Sickness benefit } \\
\text { duration }\end{array}$ & $\begin{array}{l}\text { one year or more, short } \\
\text { or no wage payment period }\end{array}$ & $\begin{array}{l}\text { one year or more, significant } \\
\text { wage payment period }\end{array}$ & $\begin{array}{l}\text { six-twelve months, short } \\
\text { or no wage payment period }\end{array}$ & $\begin{array}{l}\text { six-twelve months, } \\
\text { significant wage payment } \\
\text { period }\end{array}$ & $\begin{array}{l}\text { less than } 6 \text { months, short } \\
\text { or no wage payment period }\end{array}$ & $\begin{array}{l}\text { less than } 6 \text { months, } \\
\text { significant wage payment } \\
\text { period }\end{array}$ \\
\hline $\begin{array}{l}\text { x10. Unemployment benefit } \\
\text { level and duration }\end{array}$ & $\begin{array}{l}\mathrm{DI}>\text { UE level, short duration } \\
\text { of unemployment }\end{array}$ & $\begin{array}{l}\mathrm{DI}>\mathrm{UE} \text { level, long duration } \\
\text { of unemployment }\end{array}$ & $\begin{array}{l}\text { similar levels, short duration } \\
\text { of unemployment }\end{array}$ & $\begin{array}{l}\text { similar levels, long duration } \\
\text { of unemployment }\end{array}$ & $\begin{array}{l}\mathrm{DI}<\mathrm{UE} \text { level, short duration } \\
\text { of unemployment }\end{array}$ & $\begin{array}{l}\mathrm{DI}<\text { UE level, long duration } \\
\text { of unemployment }\end{array}$ \\
\hline
\end{tabular}

$\mathrm{RR}$ = Replacement rate; $\mathrm{DI}$ = Disability benefit; UE = Unemployment benefit.

Source: $O E C D$. 


\section{Discussion Paper Series}

Mannheim Research Institute for the Economics of Aging Universität Mannheim

To order copies, please direct your request to the author of the title in question.

\begin{tabular}{|c|c|c|c|}
\hline Nr. & Autoren & Titel & Jahr \\
\hline $123-07$ & $\begin{array}{l}\text { Karsten Hank } \\
\text { Stephanie Stuck }\end{array}$ & $\begin{array}{l}\text { Ehrenamt, Netzwerkhilfe und Pflege in Europa - } \\
\text { Komplementäre oder konkurrierende } \\
\text { Dimensionen produktiven Alterns? }\end{array}$ & 07 \\
\hline $124-07$ & Daniel Schunk & $\begin{array}{l}\text { What Determines the Saving Behavior of } \\
\text { German Households? An Examination of Saving } \\
\text { Motives and Saving Decisions }\end{array}$ & 07 \\
\hline $125-07$ & Matthias Sommer & & 07 \\
\hline $126-07$ & \begin{tabular}{|l|} 
Axel H. Börsch-Supan, \\
Anette Reil-Held, \\
Christina B. Wilke
\end{tabular} & $\begin{array}{l}\text { How an Unfunded Pension System looks like } \\
\text { Defined Benefits but works like Defined } \\
\text { Contributions: The German Pension Reform }\end{array}$ & 07 \\
\hline $127-07$ & $\begin{array}{l}\text { Karsten Hank } \\
\text { Isabella Buber }\end{array}$ & $\begin{array}{l}\text { Grandparents Caring for Their Grandchildren: } \\
\text { Findings from the } 2004 \text { Survey of Health, } \\
\text { Ageing and Retirement in Europe }\end{array}$ & 07 \\
\hline $128-07$ & Axel Börsch-Supan & $\begin{array}{l}\text { European welfare state regimes and their } \\
\text { generosity towards the elderly }\end{array}$ & 07 \\
\hline $129-07$ & $\begin{array}{l}\text { Axel Börsch-Supan } \\
\text { Alexander Ludwig } \\
\text { Mathias Sommer }\end{array}$ & Aging and Asset Prices & 07 \\
\hline $130-07$ & Axel Börsch-Supan & $\begin{array}{l}\text { Nachfrageseitiger Wettbewerb im } \\
\text { Gesundheitswesen }\end{array}$ & 07 \\
\hline $131-07$ & $\mid$\begin{tabular}{|l|} 
Florian Heiss, Axel \\
Börsch-Supan, Michael \\
Hurd, David Wise
\end{tabular} & $\begin{array}{l}\text { Pathways to Disability: Predicting Health } \\
\text { Trajectories }\end{array}$ & 07 \\
\hline $132-07$ & Axel Börsch-Supan & Rational Pension Reform & 07 \\
\hline $133-07$ & Axel Börsch-Supan & Über selbststabilisierende Rentensysteme & 07 \\
\hline $134-07$ & $\begin{array}{l}\text { Axel Börsch-Supan, } \\
\text { Hendrik Jürges }\end{array}$ & $\begin{array}{l}\text { Early Retirement, Social Security and Well- } \\
\text { Being in Germany }\end{array}$ & 07 \\
\hline $135-07$ & Axel Börsch-Supan & Work Disability, Health, and Incentive Effects & 07 \\
\hline
\end{tabular}

